\title{
Potassium-induced alleviation of salinity stress in Brassica campestris L.
}

Research Article

\author{
Shahid Umar ${ }^{1, *}$, Iram Diva ${ }^{1}$, Naser A. Anjum²,*, Muhammad Iqbal ${ }^{3}$, Iqbal Ahmad²,4, \\ Eduarda Pereira ${ }^{2}$ \\ 'Department of Botany, Hamdard University, \\ New Delhi-110 062, India \\ ${ }^{2}$ Centre for Environmental and Marine Studies (CESAM) \& Department of Chemistry, \\ University of Aveiro, 3810-193 Aveiro, Portugal \\ ${ }^{3}$ Department of Plant Production, College of Food \& Agricultural Sciences, \\ King Saud University, Riyadh 11451, Saudi Arabia \\ ${ }^{4}$ Centre for Environmental and Marine Studies (CESAM) \& Department of Biology, \\ University of Aveiro, 3810-193 Aveiro, Portugal
}

Received 22 February 2011; Accepted 07 June 2011

Abstract: Salinity is an important abiotic factor that adversely affects major agricultural soils of the world and hence limits crop productivity. An optimum mineral-nutrient status of plants plays critical role in determining plant tolerance to various stresses. A pot experiment was conducted on mustard (Brassica campestris L.) to study the protective role of added potassium (K, $40 \mathrm{mg} \mathrm{kg}^{-1}$ soil) against salinity-stress $(0,40$ and $80 \mathrm{mM} \mathrm{NaCl})$-induced changes in plant growth, photosynthetic traits, ion accumulation, oxidative stress, enzymatic antioxidants and non-enzymatic antioxidants at 30 days after sowing. Increasing $\mathrm{NaCl}$ levels decreased the growth, photosynthetic traits and the leaf ascorbate and glutathione content but increased the leaf ion accumulation and oxidative stress, and the activity of antioxidant enzymes. In contrast, K-nutrition improved plant growth, photosynthetic traits, activity of antioxidant enzymes and the ascorbate and glutathione content, and reduced ion accumulation and oxidative stress traits in the leaves, more appreciably at $40 \mathrm{mM}$ than at $80 \mathrm{mM} \mathrm{NaCl}$. The study illustrates the physiological and biochemical basis of K-nutrition-induced $\mathrm{NaCl}$ tolerance in mustard as a means to achieving increased crop productivity in a sustainable way.

Keywords: Antioxidant defence system • Brassica campestris • Ion accumulation • Oxidative stress • Plant growth • Potassium nutrition - Soil-salinity

(c) Versita Sp. z 0.0 .

\section{Abbreviations}

$\begin{array}{ll}\text { APX } & \text { - ascorbate peroxidase; } \\ \text { AsA } & \text { - ascorbate (reduced); } \\ \text { DAS } & \text { - days after sowing; } \\ \text { DHA } & \text { - dehydroascorbate; } \\ \text { DTNB } & \text { - 5',5'-dithio-bis-2-nitro-benzoic acid; } \\ \text { DTT } & \text { - 1,4-dithiothreitol; } \\ \text { EDTA } & \text { - ethylenediaminetetraacetic acid; } \\ \text { FW } & \text { - fresh weight; } \\ \text { GR } & \text { - glutathione reductase; } \\ \text { GSH } & \text { - glutathione (reduced); } \\ \text { GSSG } & \text { - glutathione (oxidized); } \\ \text { LA } & \text { - leaf area; } \\ \text { MBTH } & \text { - 3-methyl-2-benzothiazoline hydrazone; } \\ \text { NBT } & \text { - nitroblue tetrazolium; } \\ \text { NEM } & \text { - N'N-ethylemaleimide; }\end{array}$

$\mathrm{P}_{\mathrm{N}} \quad$ - net photosynthetic rate;

ROS - reactive oxygen species;

SOD - superoxide dismutase;

TBARS - thiobarbituric acid reactive substances.

\section{Introduction}

Salt affected soils are an integral part of the landscape in arid and semiarid tropical and/or non-tropical regions. It is estimated that approximately 831 million hectare (mha) are affected world wide, which accounts for more than $6 \%$ of the world's land surface area [1]. Plants growing in salt affected soils are exposed to a number of unfavourable conditions which include low soil water potential, nutrient imbalance and excessive $\mathrm{Na}^{+}$and $\mathrm{Cl}^{-}$accumulation and/or $\mathrm{K}^{+}$deficiency in cells [2-4]. The cumulative effects

*E-mail:shahidumar08@yahoo.com; anjum@ua.pt 
of all the above factors adversely affect physiological and biochemical processes of plants leading to poor growth and yield $[5,6]$. Oxidative damage at the cellular/ organ level under adverse conditions including salt stress resulting from the imbalance between production of reactive oxygen species (ROS) and antioxidant defence is often studied to understand the mechanisms of injury $[4,7]$. ROS are highly reactive and cause damage to major cellular components [8]. Plant tolerance to salinity stress may be due to ion homeostasis, osmotic adjustment and efficient and synchronous action of various enzymatic and non-enzymatic components of the antioxidant defence system [6]. A level of nutrients considered being sufficient for plant growth under non-stress conditions may or may not be sufficient under salt stress. Where plant growth is also adversely affected because of higher nutrient requirement under salt stress, increased supply of nutrients is likely to benefit plants under stress $[9,10]$. Grattan and Grieve [11] have extensively reviewed the impact of increased nutrient supply on horticultural crops under salt stress.

The macronutrient potassium $(\mathrm{K})$ plays an important role in stimulation of root growth, increasing leaf area, chlorophyll content, net assimilation rate, balancing membrane potential and turgor, activating enzymes, regulating osmotic pressure, stomatal movement and tropisms and reduction of the excess uptake and translocation of ions such as $\mathrm{Na}^{+}$and $\mathrm{Cl}^{-}[12,13]$. The antagonistic effect of $\mathrm{Na}^{+}$(the predominant cation in salt affected soil) on uptake of $\mathrm{K}$ is well established. Externally supplied $\mathrm{K}$ may also increase endogenous $\mathrm{K}^{+}$content of seeds, required to tolerate salinity at germination [14], and ameliorate abiotic-stress effects [13]. However, there is limited understanding of the mechanisms associated with $\mathrm{K}$ alleviating the adverse effects of salt stress accrued oxidative stress in plants.

The present study is aimed at studying the effects of added $\mathrm{K}$ (through nutrient solution) on photosynthetic functions, reducing equivalents (AsA-GSH) and control of the coordination of enzymatic (SOD, APX, GR) and non-enzymatic (AsA, GSH) in pot culture raised-Brassica campestris plants exposed to varying salinity levels. The outcome of the study may be helpful in formulating a protocol for the application of a proper level of $\mathrm{K}$ to $\mathrm{NaCl}$-affected soil which consequently may be helpful in achieving increased crop productivity in a sustainable way.

\section{Experimental Procedures}

\subsection{Plant material and growth conditions}

Seedlings of mustard (Brassica campestris L. cv. Pusa Gold) were raised from seeds in $40-\mathrm{cm}$-diameter plastic pots filled with $8 \mathrm{~kg}$ soil. The experimental soil had the following characteristics: texture - loamy sand $(83.6 \%$ sand, $6.8 \%$ silt and $9.6 \%$ clay), pH - 7.1, E.C. $-0.23 \mathrm{dsm}^{-1}$, organic C $-0.28 \%$, available $\mathrm{P}-14 \mathrm{~kg} \mathrm{ha}^{-1}$, available $\mathrm{K}-158 \mathrm{~kg} \mathrm{ha}^{-1}$ [15]. The experiment was carried out during winter under natural day/night [photosynthetically active radiation (PAR) $>900 \mu \mathrm{mol}$ (photon) $\mathrm{m}^{-2} \mathrm{~s}^{-1}$, temperature $22 \pm 3^{\circ} \mathrm{C}$; relative humidity $(\mathrm{RH}) 62-72 \%$ in the Department of Botany, Hamdard University, New Delhi, India (28.380' N, 77.110' E and 228 m altitude). Two plants per pot were grown with Hoagland's nutrient solution [16] and were fed with $250 \mathrm{ml}$ of nutrient solution with 0 (control), $40,80 \mathrm{mM} \mathrm{NaCl}$ solution (i.e. $0.001,5.0$, and $8.0 \mathrm{dS} \mathrm{m} \mathrm{m}^{-1}$, respectively) every alternate day and $200 \mathrm{ml}$ of deionized water daily. Extra $\mathrm{K}(\mathrm{KCl}$, Analytical grade) was applied at $40 \mathrm{mg} \mathrm{kg}^{-1}$ soil once at the start of the study. The pots were arranged in a randomized block design and replicated three times. All the measurements were performed at $30 \mathrm{~d}$ after sowing (DAS).

\subsection{Measurements of growth and photosynthetic traits}

Plant dry mass (PDM) was recorded after drying the plants for $48 \mathrm{~h}$ to a constant weight at $80^{\circ} \mathrm{C}$. Leaf area (LA) was measured by a leaf area meter (Licor 300 model). Net photosynthetic rate $\left(\mathrm{P}_{\mathrm{N}}\right)$, stomatal conductance (gs) and intercellular $\mathrm{CO}_{2}$ concentration (Ci) were measured on a fully expanded third leaf from the top of the main shoot, using an infra red gas analyzer (Licor 6400 model) at 9:00-11:00 am at saturating light intensity.

\subsection{Oxidative stress traits}

\subsubsection{Thiobarbituric acid reactive substances content}

For measuring lipid peroxidation, the content of thiobarbituric acid reactive substances (TBARS) was measured by the method of Cakmak and Horst [17], recording the absorbance at $532 \mathrm{~nm}$ and correcting it for non-specific turbidity by subtracting the absorbance at $600 \mathrm{~nm}$. The TBARS content was calculated using the extinction coefficient of $155 \mathrm{mM}^{-1} \mathrm{~cm}^{-1}$.

\subsection{2 $\mathrm{H}_{2} \mathrm{O}_{2}$ content}

$\mathrm{H}_{2} \mathrm{O}_{2}$ assay was done according to Okuda et al. [18]. Fresh leaf $(0.5 \mathrm{~g})$ was homogenized in $2.0 \mathrm{ml}$ of prechilled $\mathrm{HClO}_{4}(0.2 \mathrm{~N})$, and the homogenate was centrifuged at $20,000 \times \mathrm{g}$ for $5 \mathrm{~min}$. To remove $\mathrm{HClO}_{4}$, the supernatant was neutralized to $\mathrm{pH} 7.5$ with $\mathrm{KOH}$ $(4 \mathrm{~N})$, followed by centrifugation at $1,000 \times \mathrm{g}$ for $1 \mathrm{~min}$. Ten units of catalase were added to an aliquot, and the mixture was incubated for $15 \mathrm{~min}$ at $25^{\circ} \mathrm{C}$. The reaction was stopped by boiling for $1 \mathrm{~min}$. The reaction mixture $(1.5 \mathrm{ml})$ contained $1.0 \mathrm{ml}$ of aliquot, $400 \mu \mathrm{l}$ of 3-(dimethylamino) benzoic acid (DMAB, $12.5 \mathrm{mM}$ ) 
prepared in phosphate buffer $(0.375 \mathrm{M}, \mathrm{pH} 6.5), 80 \mu \mathrm{l}$ of 3-methyl-2-benzothiazoline hydrazone (MBTH) and $20 \mu \mathrm{l}$ of peroxidase ( 0.25 unit). The reaction was started by the addition of peroxidase, and the increase in absorbance was recorded at $590 \mathrm{~nm}$.

\subsection{Components of the antioxidant defence system}

\subsubsection{Contents of non-enzymatic components - reduced ascorbate and glutathione}

The content of reduced (GSH) glutathione was estimated following the method of Anderson [19]. Fresh leaf $(0.5 \mathrm{~g})$ was homogenized in $2.0 \mathrm{ml}$ of $5 \%(\mathrm{w} / \mathrm{v})$ sulphosalicylic acid at $4^{\circ} \mathrm{C}$. The homogenate was centrifuged at $10,000 \times \mathrm{g}$ for $10 \mathrm{~min}$. To $0.5 \mathrm{ml}$ of supernatant, $0.6 \mathrm{ml}$ of K-phosphate buffer (100 mM, pH 7.0) and $40 \mu \mathrm{l}$ of $5^{\prime} 5^{\prime}$ dithiobis-2-nitrobenzoic acid (DTNB) were added and absorbance was recorded after 2 min at $412 \mathrm{~nm}$ on a UV-VIS spectrophotometer (Lambda Bio 20, Perkin Elmer, MA, USA).

The content of reduced (AsA) ascorbate was determined by the method of Law et al. [20]. Fresh leaf $(0.5 \mathrm{~g})$ was homogenized in $2.0 \mathrm{ml}$ of K-phosphate buffer (100 mM, pH 7.0) containing $1 \mathrm{mM}$ EDTA and centrifuged at $10,000 \times \mathrm{g}$ for $10 \mathrm{~min}$. To $1.0 \mathrm{ml}$ of supernatant, $0.5 \mathrm{ml}$ of $10 \%(\mathrm{w} / \mathrm{v})$ trichloroactetic acid (TCA) was added, thoroughly mixed and incubated for $5 \mathrm{~min}$ at $4^{\circ} \mathrm{C}$. To $1.5 \mathrm{ml}$ of the above solution, $0.5 \mathrm{ml}$ of $\mathrm{NaOH}(0.1 \mathrm{M})$ was mixed and centrifuged at $5,000 \times \mathrm{g}$ for $10 \mathrm{~min}$ at $20^{\circ} \mathrm{C}$. The aliquot thus obtained was equally distributed into two separate microfuge tubes $(750 \mu \mathrm{l}$ each). For estimation of AsA, $200 \mu \mathrm{l}$ of K-phosphate buffer (150 mM, pH 7.4) was added to $750 \mu \mathrm{l}$ of aliquot. For DHA estimation, $750 \mu \mathrm{l}$ of aliquot was added to $100 \mu \mathrm{l}$ of 1,4-dithiothreitol (DTT) followed by vortex-mixing, incubation for $15 \mathrm{~min}$ at $20^{\circ} \mathrm{C}$ and addition of $100 \mu \mathrm{l}$ of $0.5 \%(\mathrm{w} / \mathrm{v}) \mathrm{NEM}$. Both the microfuge tubes were then incubated for $30 \mathrm{~s}$ at room temperature. To each sample tube, $400 \mu \mathrm{l}$ of $10 \%(\mathrm{w} / \mathrm{v})$ TCA, $400 \mu \mathrm{l}$ of $\mathrm{H}_{3} \mathrm{PO}_{4}, 400 \mu \mathrm{l}$ of $4 \%$ (w/v) bipyridyl dye (N'N-dimethyl bipyridyl) and $200 \mu \mathrm{l}$ of $3 \%(\mathrm{w} / \mathrm{v}) \mathrm{FeCl}_{3}$ were added and thoroughly mixed. Absorbance was recorded at $525 \mathrm{~nm}$ after incubation for $1 \mathrm{~h}$ at $37^{\circ} \mathrm{C}$.

\subsubsection{Assays of enzymatic components}

Fresh leaf $(0.5 \mathrm{~g})$ was homogenized in K-phosphate buffer (100 mM, pH 7.0) containing 0.5\% (v/v) Triton X-100 and $1 \%(\mathrm{w} / \mathrm{v})$ polyvinylpyrrolidone (PVP) in a pre-chilled mortar and pestle. The homogenate was centrifuged at $15,000 \times g$ for $20 \mathrm{~min}$ at $4^{\circ} \mathrm{C}$. The supernatant was used for the enzyme assays. For APX, the homogenizing buffer was supplemented with $2 \mathrm{mM}$ ascorbate.

Superoxide dismutase (SOD) activity was assayed by monitoring the inhibition of photochemical reduction of nitroblue tetrazolium (NBT), according to Dhindsa et al. [21]. One unit of SOD was defined as the amount of enzyme required to cause $50 \%$ inhibition of the NBT reaction.

Activity of ascorbate peroxidise (APX) was determined according to Nakano and Asada [22] and calculated by using extinction coefficient $2.8 \mathrm{mM}^{-1} \mathrm{~cm}^{-1}$. One unit of enzyme was the amount necessary to decompose $1.0 \mu \mathrm{mol}$ of the substrate $\mathrm{min}^{-1}$ at $25^{\circ} \mathrm{C}$.

Glutathione reducatse (GR) activity was determined, following Foyer and Halliwell [23], by monitoring the GSH-dependent oxidation of NADPH. It was calculated by using the extinction coefficient $6.2 \mathrm{mM}^{-1} \mathrm{~cm}^{-1}$. One unit of enzyme was the amount necessary to decompose $1.0 \mu \mathrm{mol}$ of $\mathrm{NADPH} \mathrm{min}^{-1}$ at $25^{\circ} \mathrm{C}$.

\section{$2.5 \mathrm{Na}^{+}, \mathrm{Cl}^{-}$and $\mathrm{K}^{+}$contents}

$\mathrm{Na}^{+}$and $\mathrm{Cl}^{-}$content was determined in digested plant samples as described by Khan et al. [6] using Tri acid mixture (TAM). TAM is a mixture of nitric acid, sulphuric acid and perchloric acid (10:5:4). $\mathrm{Na}^{+}$content in the digested samples of root and leaf was estimated using a flame photometer (2273, Khera, New Delhi, India) and values were compared with a standard curve prepared from $\mathrm{NaCl}$. The content of $\mathrm{Cl}^{-}$in digested root and leaf samples was estimated by titration against $0.02 \mathrm{~N}$ silver nitrate solution using $5 \% \mathrm{~K}_{2} \mathrm{CrO}_{4}$ as indicator.

$\mathrm{K}^{+}$was estimated by the method of Lindner [24]. Potassium (K) was analyzed in the digested sample using flame photometry. The instrument was adjusted to zero $(0 \mathrm{ppm}), 25,50$ and $100 \mathrm{ppm}$ readings. The readings were recorded directly in ppm and converted to actual values of $\mathrm{K}$ in plant samples by multiplying by a dilution factor and expressed as \%.

\subsection{Statistical analysis}

The data were analysed statistically and standard errors calculated. Analysis of variance (ANOVA) was performed using SPSS (10.0 Inc., USA). The presented mean values were separated using Duncan's Multiple Range Test (DMRT) at $P \leq 0.05$.

\section{Results}

\subsection{Growth and photosynthetic traits}

Increasing salinity stress had an inhibitory effect on plant dry mass, leaf area, net photosynthesis, stomatal conductance and intercellular $\mathrm{CO}_{2}$ concentration. These variables declined by $21.47 \%, 15.0 \%, 13.0 \%$, $33.3 \%$ and $8.52 \%$, at $40 \mathrm{mM} \mathrm{NaCl}$ and by $42.9 \%$, $66.4 \%, 37.0 \%, 51.2 \%$ and $42.6 \%$, at $80 \mathrm{mM} \mathrm{NaCl}$ in comparison with respective values in the control 
( $0 \mathrm{mM} \mathrm{NaCl})$. Supply of $\mathrm{K}$ (40 $\mathrm{mg} \mathrm{kg}^{-1}$ soil) maximally mitigated the $40 \mathrm{mM} \mathrm{NaCl}$-caused decrease in plant dry mass, leaf area and photosynthetic traits. Compared with controls, only $5.0 \%, 6.6 \%, 1.3 \%, 7.6 \%$ and $2.8 \%$ increase was noticed in plant dry mass, leaf area, net photosynthesis, stomatal conductance and intercellular $\mathrm{CO}_{2}$ concentration respectively (Figure 1).

\subsection{Oxidative stress traits and $\mathrm{Na}^{+}, \mathrm{Cl}^{-}$and $\mathrm{K}^{+}$}

Figure 2 shows that the level of lipid peroxidation, in terms of TBARS content, increased with an increase in the degree of soil salinity. Soil $\mathrm{NaCl}(80 \mathrm{mM})$ caused a significantly high lipid peroxidation and $\mathrm{H}_{2} \mathrm{O}_{2}$ generation. The contents of TBARS, $\mathrm{H}_{2} \mathrm{O}_{2}, \mathrm{Na}^{+}$and $\mathrm{Cl}$ increased by $116.3 \%, 150.5 \%$, $129.3 \%$ and $51.8 \%$ respectively, due to application of $40 \mathrm{mM} \mathrm{NaCl}$, compared with the control. These variables increased by $365.2 \%, 531.3 \%, 219.0 \%$ and $98.4 \%$ respectively, at $80 \mathrm{mM} \mathrm{NaCl}$ salinity. However, addition of K (40 $\mathrm{mg} \mathrm{K} \mathrm{kg}^{-1}$ soil) completely alleviated the adverse effects of $40 \mathrm{mM} \mathrm{NaCl}$ salinity in terms of increased TBARS, $\mathrm{H}_{2} \mathrm{O}_{2}$, $\mathrm{Na}^{+}$and $\mathrm{Cl}$ contents. Even at $80 \mathrm{mM} \mathrm{NaCl}, \mathrm{K}$ fertilisation significantly mitigated the adverse effects of salinity stress on these parameters. The $\mathrm{K}^{+}$content was decreased by $14.1 \%$ and $21.1 \%$ under the influence of 40 and $80 \mathrm{mM}$ $\mathrm{NaCl}$, respectively, compared with the control. Whereas, the addition of $\mathrm{K}$ improved $\mathrm{K}$ content at both levels of salinity. The maximum (3.8\%) increase was observed when $40 \mathrm{mg} \mathrm{K} \mathrm{kg}^{-1}$ soil was supplied (Figure 2).

\subsection{Non-enzymatic and enzymatic components of the antioxidant defence system}

AsA and GSH content decreased by $16.6 \%$ and $20.5 \%$ in plants exposed to $40 \mathrm{mM} \mathrm{NaCl}$ and by $30.1 \%$ and $67.9 \%$ at $80 \mathrm{mM} \mathrm{NaCl}$. However, at $40 \mathrm{mM} \mathrm{NaCl}$, added $\mathrm{K}$ helped to reverse this decrease and values reached parity with those in plants at $0 \mathrm{mM} \mathrm{NaCl}$ (Table 1). At
$80 \mathrm{mM} \mathrm{NaCl}, \mathrm{K}$ application was effective in reducing the adverse effects of salinity on AsA and GSH.

The activities of SOD, APX and GR enzymes were increased over the control in response to salt stress. These increases were $29.2,62.6$ and $16.6 \%$ respectively at $40 \mathrm{mM} \mathrm{NaCl}$, and $45.1,79.8$ and $92.2 \%$ at $80 \mathrm{mM} \mathrm{NaCl}$. The addition of $\mathrm{K}$ to plants grown at $40 \mathrm{mM} \mathrm{NaCl}$ showed a tendency to achieve the SOD level of unstressed plants $(0 \mathrm{mM} \mathrm{NaCl})$, with a $13.2 \%$ increase. This was also true with plants at $80 \mathrm{mM} \mathrm{NaCl}$ with added $\mathrm{K}$. In contrast, there was a further increase in the activity of APX and GR in response to added $\mathrm{K}$ both at $40 \mathrm{mM}$ and $80 \mathrm{mM} \mathrm{NaCl}$. There was a $74.4 \%$ and $85.5 \%$ increase, respectively, in APS and GR activities at $40 \mathrm{mM} \mathrm{NaCl}$ compared with the control. When $80 \mathrm{mM} \mathrm{NaCl}$ treated plants were supplemented with the same $\mathrm{K}$ dose the same trend of increase in activity of these enzymes was observed over the control. The increase in APX and GR was $85.4 \%$ and $96.4 \%$ respectively (Table 2 ).

\begin{tabular}{l|cc}
\hline Treatments & $\begin{array}{c}\text { AsA content } \\
\left(\mathrm{nmol} \mathrm{g}{ }^{-1} \mathrm{FW}\right)\end{array}$ & $\begin{array}{c}\text { GSH content } \\
\left(\mathrm{nmol} \mathrm{g}{ }^{-1} \mathrm{FW}\right)\end{array}$ \\
\hline \hline Control & $186^{\mathrm{d}} \pm 22.32$ & $312^{\mathrm{a}} \pm 37.44$ \\
& $155^{\mathrm{f}} \pm 18.60$ & $248^{\mathrm{b}} \pm 29.76$ \\
& $(-16.67)$ & $(-20.51)$ \\
$40 \mathrm{mM} \mathrm{NaCl}$ & $191^{\mathrm{c}} \pm 22.92$ & $318^{\mathrm{a}} \pm 38.16$ \\
& $(2.69)$ & $(1.92)$ \\
& $130^{\mathrm{g}} \pm 15.60$ & $100^{\mathrm{h}} \pm 12.00$ \\
$80 \mathrm{mM} \mathrm{NaCl}+40 \mathrm{mg} \mathrm{K} \mathrm{kg}^{-1}$ soil & $(-30.11)$ & $(-67.95)$ \\
& $162^{\mathrm{e}} \pm 19.44$ & $129^{\mathrm{g}} \pm 15.48$ \\
& $(-12.90)$ & $(-58.65)$ \\
\hline
\end{tabular}

Table 1. Contents of ascorbate (AsA) and glutathione (GSH) in Brassica campestris $\mathrm{L}$. leaves as influenced by $\mathrm{NaCl}$ stress and $\mathrm{K}$ nutrition at $30 \mathrm{~d}$ after sowing. Values [means $\pm \mathrm{SE}(n=3)]$ in parenthesis show percent variation over the control and the values showing the same letter within the same column are not significantly different at $P \leq 0.05$, according to Duncan's Multiple Range Test. FW = Fresh weight.

\begin{tabular}{|c|c|c|c|}
\hline Treatments & $\begin{array}{c}\text { SOD activity } \\
\left(\mathrm{mg}^{-1} \text { protein } \mathrm{m}^{-1}\right)\end{array}$ & $\begin{array}{c}\text { APX activity } \\
\left(\mathrm{mg}^{-1} \text { protein } \mathrm{m}^{-1}\right)\end{array}$ & $\begin{array}{c}\text { GR activity } \\
\left(\mathrm{mg}^{-1} \text { protein } \mathrm{m}^{-1}\right)\end{array}$ \\
\hline Control & $5.10^{d} \pm 0.40$ & $0.541^{j} \pm 0.04$ & $0.160^{k} \pm 0.011$ \\
\hline $40 \mathrm{mM} \mathrm{NaCl}$ & $\begin{array}{c}7.21^{\circ} \pm 0.57 \\
(29.26)\end{array}$ & $\begin{array}{c}1.45^{i} \pm 0.11 \\
(62.69)\end{array}$ & $\begin{array}{c}0.192^{k} \pm 0.013 \\
(16.67)\end{array}$ \\
\hline $40 \mathrm{mM} \mathrm{NaCl}+40 \mathrm{mg} \mathrm{K} \mathrm{kg}^{-1}$ soil & $\begin{array}{l}5.88^{\mathrm{d}} \pm 0.47 \\
\quad(13.27)\end{array}$ & $\begin{array}{l}2.12^{\mathrm{h}} \pm 0.16 \\
\quad(74.48)\end{array}$ & $\begin{array}{c}2.11^{\mathrm{h}} \pm 0.14 \\
(85.59)\end{array}$ \\
\hline $80 \mathrm{mM} \mathrm{NaCl}$ & $\begin{array}{c}9.30^{\mathrm{a}} \pm 0.83 \\
(45.16)\end{array}$ & $\begin{array}{c}2.69^{\dagger} \pm 0.21 \\
(79.89)\end{array}$ & $\begin{array}{c}2.35^{9} \pm 0.16 \\
(92.20)\end{array}$ \\
\hline $80 \mathrm{mM} \mathrm{NaCl}+40 \mathrm{mg} \mathrm{K} \mathrm{kg}^{-1}$ soil & $\begin{array}{c}8.55^{b} \pm 0.68 \\
(40.35)\end{array}$ & $\begin{array}{c}3.71^{e} \pm 0.29 \\
(85.42)\end{array}$ & $\begin{array}{c}2.88^{f} \pm 0.20 \\
(96.53)\end{array}$ \\
\hline
\end{tabular}

Table 2. Activity of superoxide dismutase (SOD), ascorbate peroxidise (APX) and glutathione reductase (GR) in Brassica campestris L. leaves as influenced by $\mathrm{NaCl}$ stress and $\mathrm{K}$ nutrition at $30 \mathrm{~d}$ after sowing. Values [means $\pm \mathrm{SE}(n=3)$ ] in parenthesis show percent variation over the control and the values showing the same letter within the same column are not significantly different at $P \leq 0.05$, according to Duncan's Multiple Range Test. 

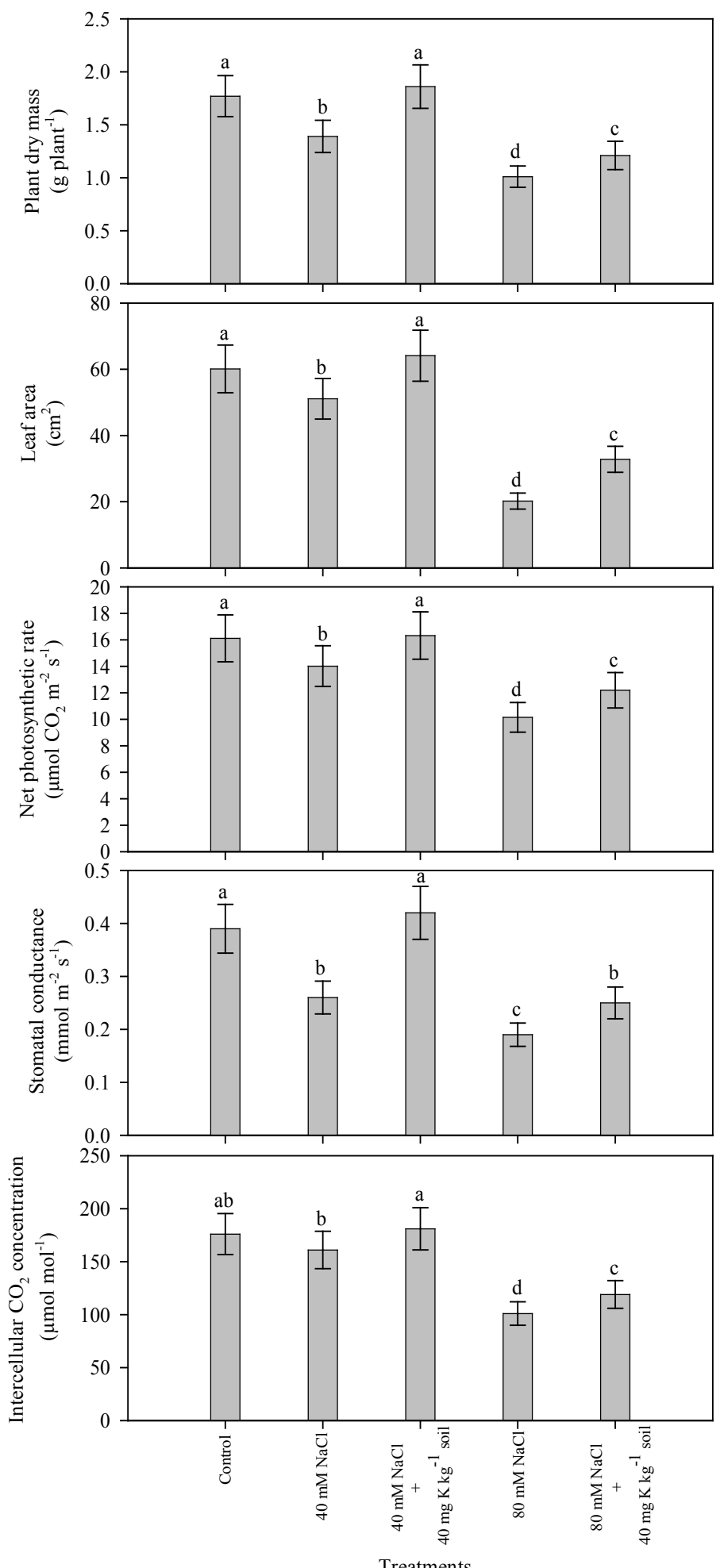

Figure 1. Plant dry mass, leaf area, net photosynthetic rate, stomatal conductance and intercellular $\mathrm{CO}_{2}$ concentration in Brassica campestris $\mathrm{L}$. as influenced by $\mathrm{NaCl}$ stress and $\mathrm{K}$ nutrition at $30 \mathrm{~d}$ after sowing. Values are means $\pm \mathrm{SE}(n=3)$. Bars showing the same letter are not significantly different at $P \leq 0.05$, according to Duncan's Multiple Range Test. 

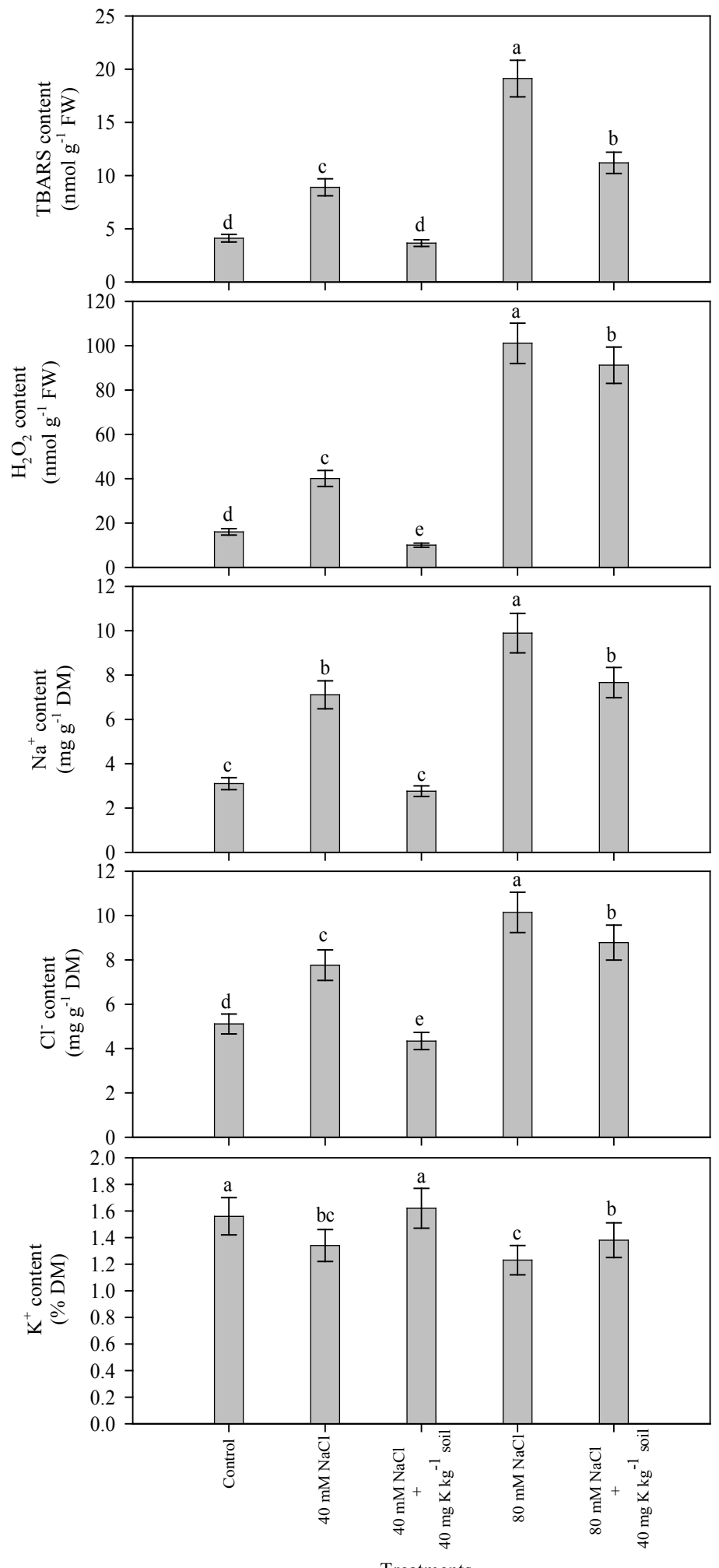

Figure 2. TBARS, $\mathrm{H}_{2} \mathrm{O}_{2}, \mathrm{Na}^{+}, \mathrm{Cl}^{-}$and $\mathrm{K}^{+}$contents in Brassica campestris $\mathrm{L}$. leaves as influenced by $\mathrm{NaCl}$ stress and $\mathrm{K}$ nutrition at $30 \mathrm{~d}$ after sowing. Values are means $\pm \mathrm{SE}(n=3)$. Bars showing the same letter are not significantly different at $P \leq 0.05$, according to Duncan's Multiple Range Test. 


\section{Discussion}

The adverse effect of increased soil-salinity on plant growth and development has been widely documented $[2,6,25]$. Growth and development are an outcome of coordination of the main biological processes in plants [26]. Availability of nutrients and the presence of stressors influence overall growth performance. Nutrient availability can be positively correlated whereas stress conditions are often negatively correlated to growth phenomena [27].

In the present study, increase in soil salinity caused a significant decline in leaf area and plant dry mass. Leaf area is considered a sensitive measure if effect in various salt-stressed plants and is also regarded as a major factor responsible for decreased dry mass of the affected individuals $[25,28]$. Reduction in leaf area expansion due to salinity stress has been observed in pepper [29,30] and strawberry [31]. The decrease in leaf area is attributed to decreased leaf cellular expansion and/or to physiological disorders triggered by salt stress, accumulation of $\mathrm{Na}^{+}$and $\mathrm{Cl}^{-}$in different plant tissues and by reduction of net photosynthesis rate and chlorophyll content in leaf tissue $[27,28]$. Reduction in leaf area means reduction in size of the solar panel to harvest solar energy [32] Even if the rate of photosynthesis remains unaffected under stress, decrease in leaf area itself is likely to have a negative impact on total dry matter production. Potassium application $\left(40 \mathrm{mg} \mathrm{K} \mathrm{kg}^{-1}\right.$ soil) mitigated the adverse effects of salinity stress and improved the leaf area and plant dry mass significantly (Figure 1). K nutrition restored the $\mathrm{NaCl}$-induced decline in the $\mathrm{K}^{+}$and $\mathrm{Ca}^{2+}$ content in plants and might help in improving the growth of stressed plants in terms of leaf area, leaf dry mass and plant dry mass. Our findings are in agreement with those of Arshi et al. [28] and Elkhatib et al. [33].

Salinity stress (40 and $80 \mathrm{mM} \mathrm{NaCl}$ ) severely affected the photosynthetic traits such as net photosynthetic rate $\left(P_{N}\right)$, stomatal conductance (gs) and intercellular $\mathrm{CO}_{2}$ concentration (Ci). This agrees with the finding of others in various plant species $[5,34]$. Added $\mathrm{K}$ improved these traits considerably in the present study. High $\mathrm{K}$ concentrations in the stroma are reported to be necessary to maintain optimum photosynthetic capacity under stress conditions [35]. Added $\mathrm{K}$ at both the salinity levels $(40$ and $80 \mathrm{mM})$ significantly improved stomatal conductance, net photosynthesis, leaf area and plant dry weight. The values for these attributes in plants exposed to $40 \mathrm{mM}$ $\mathrm{NaCl}$ were at par with those of unstressed plants $(0 \mathrm{mM} \mathrm{NaCl})$, as if the plants were not experiencing any stress. However, at $80 \mathrm{mM} \mathrm{NaCl}, \mathrm{K}$ application did little to towards bringing parity with the control level $(0 \mathrm{mM} \mathrm{NaCl})$. Salt stress resulted in a decrease in intracellular $\mathrm{CO}_{2}$ concentration particularly at $80 \mathrm{mM}$ $\mathrm{NaCl}$, and $\mathrm{K}$ fertilization did help to improve this. Like other attributes mentioned above, it was at parity with the control $(0 \mathrm{mM} \mathrm{NaCl})$ but not significantly different from the value at $40 \mathrm{mM} \mathrm{NaCl}$. At $80 \mathrm{mM} \mathrm{NaCl}$, intracellular $\mathrm{CO}_{2}$ concentration decreased significantly over the control and $\mathrm{K}$ addition improved it significantly, but it did not attain the level observed in the control.

The photosynthetic process can be negatively affected by salinity due most importantly to (i) altered stomatal closure thus limiting $\mathrm{CO}_{2}$ diffusion to the chloroplasts, (ii) modification in the structure and function of photosynthetic organelles (iii) alterations in light reactions (leading to increase in electron flux to $\mathrm{O}_{2}$ resulting consequently in an accumulation of oxidative stressors, including TBARS, in the chloroplast), and/or (iv) reduced rate of transport of assimilates and intermediary compounds to the metabolic sinks, (v) efficiency of the root system in limiting the transport of ions to shoots $[5,13,34,36,37]$.

The deleterious effects of salinity on plant growth and physiology are associated with a number of other important factors, including nutrient imbalance, the toxic effects of ions (mainly $\mathrm{Na}^{+}$and $\mathrm{Cl}^{-}$) and/or the oxidative damage resulting from imbalance between production of reactive oxygen species (ROS) and the antioxidant defence [7].

Plant tolerance to salinity stress may be due to ion homeostasis, osmotic adjustment, and a synchronous action of different components of the antioxidant defence system [6,38]. In addition, increasing evidence suggests that maintenance of the $\mathrm{K}$ status of plants plays a critical role in increasing both crop productivity and resistance to environmental stress, including salinity $[13,37]$. $\mathrm{K}$ has been shown to play a significant role in a large range of metabolic functions in plants, including growth, photosynthesis, enzyme activation and osmotic potential [27] in addition to lowering the ROS production by reducing activity of $\mathrm{NAD}(\mathrm{P}) \mathrm{H}$ oxidases and maintaining photosynthetic electron transport [13]. In this context, we have shown that the addition of $\mathrm{K}$ to the $\mathrm{NaCl}$-treated plants proved to be effective in protecting $B$. campestris plants against $\mathrm{NaCl}$-caused oxidative stress by decreasing $\mathrm{Na}^{+}$and $\mathrm{Cl}^{-}$content and increasing $\mathrm{K}^{+}$in leaves. The antagonistic effect of $\mathrm{K}^{+}$and $\mathrm{Na}^{+}$on uptake of each other is well documented and reported in both saline and sodic conditions $[10,27,39,40]$. Added $K$ also improved AsA and GSH contents, and further enhanced the activity of APX and GR, whereas the activity of SOD dropped with $\mathrm{K}$-supplementation to the $\mathrm{NaCl}$-treated plants. 
In fact, the generation of ROS is an important consequence of a number of stress factors including salinity stress in plants [6]. ROS are metabolised by an efficient antioxidant defence system wherein the enzymatic antioxidants SOD dismutase $\mathrm{O}_{2}^{--}$to $\mathrm{H}_{2} \mathrm{O}_{2}$, which is further detoxified by APX and/or catalase (data not shown), whereas non-enzymatic antioxidants AsA and GSH have a tight control over the generation and scavenging of ROS [6,39]. AsA-GSH-cycle metabolism is an essential mechanism of plant resistance under stressful conditions [38,41]. Glutathione removes excess $\mathrm{H}_{2} \mathrm{O}_{2}$ [42] and lipid peroxides keep ROS under control [43]. APX detoxifies $\mathrm{H}_{2} \mathrm{O}_{2}$ into water using AsA as the major substrate where GSH continuously regenerates AsA from DHA, the oxidized form, via the AsA-GSH cycle. In this process GSH is oxidised into GSSG, which is subsequently recycled by GR [42]. In the present study, K-supplementation to $\mathrm{NaCl}$-treated plants further enhanced the $\mathrm{GR}$ activity (maximally at $40 \mathrm{mM} \mathrm{NaCl}$ ) and thus maintained coordination between the enzymatic (SOD, APX and GR) and non-enzymatic (AsA, GSH) antioxidants. Earlier, increased glutathione content due to sulphur application had been found to protect dry mass and photosynthesis in cadmium-treated mustard (Brassica campestris) plants [43]. In addition to other physiological effects of nutrition in plants, glutathione maintains the endogenous level of $\mathrm{K}^{+}$in plant tissues and reduces the excess uptake and translocation of undesirable ions including $\mathrm{Na}^{+}$and $\mathrm{Cl}^{-}[13,14] . \mathrm{K}^{+}$is the most prominent competitor in the uptake of $\mathrm{Na}^{+}$ under salt stress [44]. K nutrition ameliorated to a great extent the $\mathrm{Na}^{+}$and $\mathrm{Cl}^{-}$- accrued decrease in reducing equivalents viz., AsA and GSH which, in turn, had a tight control over the balance between production and scavenging of $\mathrm{H}_{2} \mathrm{O}_{2}$ and stabilized the cell membrane

\section{References}

[1] Martinez-Beltran J., Manzur C.L., Overview of salinity problems in the world and FAO strategies to address the problem, Proc. Intl. Sal. For., Riverside, California, 2005

[2] Ashraf M., Harris P.J.C., Potential biochemical indicators of salinity tolerance in plants, Plant Sci., 2004, 166, 3-16

[3] Garthwaite A.J., Bothmer R.V., Colmer T.D., Salt tolerance in wild Hordeum species is associated with restricted entry of $\mathrm{Na}+$ and $\mathrm{Cl}-$ into the shoots, J. Exp. Bot., 2005, 56, 2365-2378

[4] Cuin T.A., Shabala S., Compatible solutes reduce ROS-induced potassium efflux in Arabidopsis roots, Plant Cell Env., 2007, 30, 875-885 by decreasing TBARS content through coordination with other components of the AsA-GSH cycle. Our findings that $\mathrm{K}$ nutrition improves the leaf $\mathrm{K}^{+}$and decreases the $\mathrm{Na}^{+}$and $\mathrm{Cl}^{-}$contents confirm those of Qadar and Azam [10], Zheng et al. [40,45] and More and Manchanda [39].

\section{Conclusions}

$\mathrm{NaCl}$ stress severely retarded plant growth and photosynthesis, increased the ion toxicity in terms of increasing leaf $\mathrm{Na}^{+}$and $\mathrm{Cl}^{-}$contents, induced lipid peroxidation (TBARS), caused oxidative stress $\left(\mathrm{H}_{2} \mathrm{O}_{2}\right)$ and modulated the plant antioxidant system to a great extent. $\mathrm{K}$ nutrition exhibited an antagonistic effect on $\mathrm{Na}^{+}$and $\mathrm{Cl}^{-}$accumulation, controlled the SOD and APX activities required for the removal of $\mathrm{H}_{2} \mathrm{O}_{2}$ and TBARS, and up-regulated GR activity to improve the cellular reducing equivalents $\mathrm{As} A$ and $\mathrm{GSH}$ in order to protect plants from $\mathrm{NaCl}$-caused oxidative stress. A protocol for the application of an optimal level of $\mathrm{K}$ to the $\mathrm{NaCl}$ affected soil may be developed to achieve increased crop productivity in a sustainable way.

\section{Acknowledgements}

Authors are grateful to Hamdard National Foundation (HNF), New Delhi, India for financial assistance for the work. Authors sincerely thank to Dr. Ali Qadar of Central Soil Salinity Research Institute (CSSRI), ICAR, Karnal, Haryana (India) for his valuable critical comments on the second version of this manuscript, and colleagues and staffs at Department of Botany, Hamdard University, New Delhi, for their kind support and encouragements.

[5] Munns R., James R.A., Läuchli A., Approaches to increasing the salt tolerance of wheat and other cereals, J. Exp. Bot., 2006, 57, 1025-1043

[6] Khan N.A., Nazar R., Anjum N.A. Growth, photosynthesis and antioxidant metabolism in mustard (Brassica juncea L.) cultivars differing in ATP-sulfurylase activity under salinity stress, Sci. Hortic., 2009, 122, 455-460

[7] Vital S.A., Fowler R.W., Virgen A., Gossett D.R., Banks S.W., Rodriguez J., Opposing roles for superoxide and nitric oxide in the $\mathrm{NaCl}$ stressinduced upregulation of antioxidant enzyme activity in cotton callus tissue, Env. Exp. Bot., 2008, 62, 60-68 
[8] Foyer C.H., Descourvires P., Kunert K.J., Protection against oxygen radicals: An important defence mechanism studied in transgenic plants, Plant Cell Env., 1994, 17, 507-523

[9] Qadar A., Alleviation of sodicity stress on rice genotypes by phosphorus fertilization, Plant Soil, 1998, 203, 269-277

[10] Qadar A., Zake M.A. Selecting rice genotypes tolerant to zinc deficiency and sodicity : differences in concentration of major cations and sodium/ potassium ratio in leaves, J. Plant Nutr., 2007, 30, 2061-2076

[11] Grattan S.R., Grieve C.M., Salinity nutrient relations in horticultural crops, Sci. Hortic., 1999, 78, 127-157

[12] Cherel L., Regulation of $\mathrm{K}+$ channel activities in plants: from physiological to molecular aspects, J. Exp. Bot., 2004, 55, 337-51

[13] Cakmak I., The role of potassium in alleviating detrimental effects of abiotic stresses in plants, J. Plant Nutr. Soil Sci., 2005, 168, 521-530

[14] Collins R.P., Harris P.J.C., Bateman, M.J., Henderson J., Effect of calcium and potassium nutrition on yield, ion content, and salt tolerance of Brassica campestris (rapa), J. Plant Nutr., 2008, 31, 1461-1481

[15] Diva I., Ameliorative effect of potassium on growth and yield of Brassica campestris L and Vigna radiata (L.) Wilczek under the influence of salinity, heavy metal and water stress, PhD Thesis, 2007, Jamia Hamdard, New Delhi, India

[16] Hewitt E.J. Sand and water cultural methods used in the study of plant nutrition, Comm. Agric. Bur., England, 1966, p. 56

[17] Cakmak I., Horst W.J., Effect of aluminium on lipid peroxidation, superoxide dismutase, catalase, peroxidase activities in root tips of soybean (Glycine max L.), Physiol. Plant, 1991, 83, 463-468

[18] Okuda T., Masuda Y., Yamanka A., Sagisaka S., Abrupt increase in the level of hydrogen peroxide in leaves of winter wheat is caused by cold treatment, Plant Physiol., 1991, 97, 1265-1267

[19] Anderson M.E., Determination of glutathione and glutathione disulfides in biological samples, Meth. Enzymol., 1985, 113, 548-570

[20] Law M.E., Charles S.A., Halliwell B., Glutathione and ascorbic acid in spinach (Spinacia oleracea) chloroplasts: the effect of hydrogen peroxide and of paraquat, Biochem. J., 1983, 210, 899-903

[21] Dhindsa R.H., Plumb-Dhindsa P., Thorpe T.A., Leaf senescence correlated with increased level of membrane permeability, lipid per oxidation and decreased level of SOD and CAT, J. Exp. Bot., 1981, 32, 93-101
[22] Nakano Y., Asada K., Hydrogen peroxide is scavenged by ascorbate-specific peroxidase in spinach chloroplasts, Plant Cell Physiol., 1981, 22, 867-880

[23] Foyer C.H., Halliwell B., The presence of glutathione and glutathione reductase in chloroplasts: a proposed role in ascorbic acid metabolism, Planta, 1976, 133, 21-25

[24] Lindner R.C., Rapid analytical method for some of the more common organic substances of plant and soil, Plant Physiol., 1944, 19, 76-84

[25] Munns R., Tester M., Mechanisms of salinity tolerance, Annu. Rev. Plant Biol., 2008, 59, 651-681

[26] Vassilev A., Yordanov I., Tsonev T., Physiological responses of two barley cultivars to soil pollution with cadmium, Env. Pollut., 1998, 100, 1-7

[27] Marschner H., Mineral Nutrition of Higher Plants, $2^{\text {nd }}$ Edn. Academic Press, London, 2002

[28] Arshi A., Abdin M.Z., Iqbal M., Ameliorative effects of $\mathrm{CaCl}_{2}$ on growth, ionic relations and proline content of senna under salinity stress, J. Plant Nutr., 2005, 28, 101-125

[29] Chartzoulakis K., Klapaki G., Response of two green house pepper hybrids to $\mathrm{NaCl}$ salinity during different growth stages, Sci. Hortic., 2000, 86, 247-260

[30] Muñoz-Ramos J.J., Guzmán M., Castellanos J.Z., Salinity in vegetative and reproductive growth of pepper, [Salinidad sódica en el desarrollo vegetativo y reproductivo del pimiento], Terr. LatinoAmer., 2004, 22, 187-196 (in Spanish)

[31] Saied S., Keutgen A.J., Noga G., Effects of $\mathrm{NaCl}$ stress on leaf growth, photosynthesis and ionic contents of strawberry cvs 'Elsanta2 and 'Korona', Acta Hortic., 2003, 609, 67-73

[32] Taleisnik E., Rodríguez A.A., Bustos D., Erdei L., Ortega L., Senn M.E., Leaf expansion in grasses under salt stress, J. Plant Physiol., 2009, 166, 1123-1140

[33] Elkhatib H.A., Elkhatib E.A., Khalaf Allah A.M., ElSharkawy A.M., Yield response of salt- stressed potato to potassium fertilization: A prelimnary mathematical model, J. Plant Nutr., 2004, 27, 111-122

[34] Chaves M.M., Flexas J., Pinheiro C., Photosynthesis under drought and salt stress: regulation mechanisms from whole plant to cell, Ann. Bot., 2009, 103, 551-560

[35] Chow W.S., Ball M.C., Anderson J.M., Growth and photosynthetic responses of spinach to salinity: Implications of $\mathrm{K}$ nutrition for salt tolerance, Aust. J. Plant Physiol., 1990, 17, 563-578

[36] Centritto M., Loreto F., Chartzoulakis K., The use of low $\left[\mathrm{CO}_{2}\right]$ to estimate diffusional and non- 
diffusional limitations of photosynthetic capacity of salt-stressed olive saplings, Plant Cell Environ., 2003, 26, 585-94

[37] Degl' Innocenti E., Hafsi C., Guidi L., Navari-Izzo F., The effect of salinity on photosynthetic activity in potassium-deficient barley species, J. Plant Physiol., 2009, 166, 1968-1981

[38] Anjum N.A., Umar S., Iqbal M., Khan N.A., Cadmium causes oxidative stress in moongbean [Vigna radiata (L.) Wilczek] by affecting antioxidant enzyme systems and ascorbate-glutathione cycle metabolism. Russ. J. Plant Physiol., 2011, 58, 92-99

[39] More R.P., Manchanda H.R., Influence of phosphorus on the tolerance of table pea to chloride and sulphate salinity in a sandy soil, Arid Soil Res. Rehab., 1992, 6, 41-52

[40] Zheng Y., Jia A., Ning T., Xu J., Li Z., Jiang G., Potassium nitrate application alleviates sodium chloride stress in winter wheat cultivars differing in salt tolerance, J. Plant Physiol., 2008, 165, 1455-1465
[41] Szalai G., Kellos T., Galiba G., Kocsy G., Glutathione as an antioxidant and regulatory molecule in plants under abiotic stress conditions, J. Plant Growth Regul., 2009, 28, 66-80

[42] Noctor G., Arisi A.C.M., Jouanin L., Kunert K.J., Rennenberg H., Foyer C.H., Glutathione: biosynthesis, metabolism and relationship to stress tolerance explored in transgenic plants, J. Exp. Bot., 1998, 49, 623-647

[43] Rausch T., Gromes R., Liedschulle V., Muller I., Bogs J., Galovic V., et al ., Novel insight into the regulation of GSH biosynthesis in higher plants, Plant Biol., 2007, 9, 565-572

[44] Marschner H., Mineral Nutrition of Higher Plants, Academic Press, London, 1995

[45] Zheng Y., Xu X., Simmons M., Li Z., Responses of physiological parameters, grain yield and grain quality to foliar application of potassium nitrate in two contrasting winter wheat cultivars under salinity stress, J. Plant Nutr. Soil Sci., 2010, 173, 444-452 